\title{
BULK DEPOSITION OF PESTICIDES IN A CANADIAN CITY: PART 1 GLYPHOSATE AND OTHER AGRICULTURAL PESTICIDES.
}

\author{
A. FARENHORST, L.A. ANDRONAK AND R.D.A. MCQUEEN. \\ Department of Soil Science, Faculty of Agricultural \& Food Sciences, University of Manitoba, \\ 362 Ellis Building, Winnipeg, MB, Canada
}

Address correspondence to Annemieke Farenhorst, Department of Soil Science, 13 Freedman Crescent, Faculty of Agriculture and Food Sciences, University of Manitoba, Winnipeg, MB, Canada, R3T 2N2; Telephone: 204-474-6858, Fax: 204-474-7642, E-mail:

Annemieke.Farenhorst@umanitoba.ca 


\begin{abstract}
Winnipeg is a city in the Canadian Prairies with a population of about 600,000. Like many other cities and towns in this region of Canada, the city is surrounded by agriculture. Weekly bulk deposition samples were collected from May to September in 2010 and 2011 and analyzed for forty-three pesticides used in Prairie agriculture. Fourteen herbicides, five herbicide metabolites, two insecticides and two fungicides were detected with $98.5 \%$ of the samples containing chemical mixtures. Glyphosate is the most widely used pesticide in Prairie agriculture and accounted for $65 \%$ of the total pesticide deposition over the two years. Seasonal glyphosate deposition was more than five times larger in 2011 (182 mm rain) than 2010 (487 $\mathrm{mm}$ rain), suggesting increased glyphosate particulate transport in the atmosphere during the drier year. The seasonal deposition of ten other frequently herbicides was significantly positively correlated with the amount of herbicides applied both in and around Winnipeg $(r=0.90, \mathrm{P}<0.001)$ and with agricultural herbicide use around Winnipeg $(r=0.63, \mathrm{P}=0.05)$, but not with agricultural herbicide use province wide $(\mathrm{p}=0.23)$. Herbicides 2,4-D, dicamba, and mecoprop had known urban applications and were more consistently detected in samples relative to bromoxynil and MCPA whose frequency of detections decreased throughout August and September. The Canadian Water Quality Guidelines for irrigation water were frequently exceeded for both dicamba (75\%) and MCPA (49\%) concentrations in rain. None of glyphosate concentrations in rain exceeded any of the Canadian Water Quality Guidelines established for this herbicide.
\end{abstract}

Keywords: Agricultural pesticides, urban pesticides, glyphosate, post-emergent herbicides, urban bulk deposition, water quality guidelines.

\title{
Introduction
}


The Prairie region of Canada has approximately $527,000 \mathrm{~km}^{2}$ of agricultural land. The adoption of glyphosate-resistant canola, corn and soybean crops has dramatically increased the use of glyphosate in the Prairies (Beckie et al. 2006, Duke and Bowles 2008). For example, Wilson (2012) calculated that the mass of glyphosate applied in the Province of Manitoba far exceeds that of any other pesticide used. In bulk deposition studies conducted in rural areas of the Prairies (Chang et al., 2011; Humphries et al. 2005; Messing et al., 2011; Quaghebeur et al., 2004), glyphosate was detected in 50 to $92 \%$ of the samples. Other herbicides that have been frequently detected in deposition samplers deployed in rural areas of the Prairies are 2,4-D, bromoxynil, dicamba and MCPA (Hill et al., 2003; Messing et al. 2011; Rawn et al., 1999; Waite et al., 2005). The types and masses of herbicides detected in deposition samplers have been shown to vary between municipalities in the Prairies because of the influences of nearby pesticide use (Hill et al. 2003).

Winnipeg is a city in the Canadian Prairies with a population of about 600,000. Like many other cities and towns in this region of Canada it is surrounded by agriculture. Glyphosate has been detected in urban locations in Europe in up to $10 \%$ of the bulk deposition samples collected in studies (Lamprea and Ruban 2011; Quaghebeur et al., 2004) but there are no published reports on glyphosate deposition in North American cities. Agricultural pesticide use is likely an important contributor to pesticide deposition in urban environments because deposition samplers installed in city locations closer to agricultural land show greater pesticide concentrations than deposition samplers installed in the city centre (Grynkiewicx et al. 2003). Herbicide and insecticide use within city-limits has shown to increase pesticide loadings of urban streams (Hoffman et al. 2000; Todd and Struger 2014). 
The objective of this study was to monitor for glyphosate and other pesticide deposition in a city that is surrounded by agricultural land, and estimate the relative impact of agricultural and urban use on the types and masses of pesticides detected.

\section{Materials and Methods}

Sampling stations and analysis. Study site Ridge $\left(49^{\circ} 48^{\prime} \mathrm{N}\right.$ latitude, $97^{\circ} 12^{\prime} \mathrm{W}$ longitude) is located approximately $7 \mathrm{~km}$ west of site Vital $\left(49^{\circ} 47^{\prime} \mathrm{N}\right.$ latitude, $97^{\circ} 6^{\prime} \mathrm{W}$ longitude). Both sites are in the southern part of the city, with Ridge being $3.5 \mathrm{~km}$ and Vital being $1.2 \mathrm{~km}$ north of a city perimeter that roughly separates the city from the surrounding agricultural land. The agricultural land to the south consists of near-level Red River heavy-clay soils that are dominated by wheat, oat, canola and soybean production under moderate herbicide use (Messing et al. 2014).

During 2010 and 2011 weekly bulk deposition samples were collected in each of the 18 weeks from May 18 to September 21. Bulk deposition samples were collected in a $1 \mathrm{~m}$ by $1 \mathrm{~m}$ galvanized sheet metal pan that emptied into a 23L glass carboy shaded by plywood. Each week, a subsample was collected from the carboy in an amber glass bottle (1L) with a Teflon cap, and the carboy was removed and replaced by an empty one. A meteorological station (Watch Dog 2700 Weather Station, Spectrum Technologies Inc., Plainfield, IL), installed next to the bulk deposition sampler, was used to record precipitation and temperature. During the 2010 sampling season, temperatures ranged from 4.6 to $31^{\circ} \mathrm{C}$ with an average of $487 \mathrm{~mm}$ of total rainfall across the two sites. During 2011, temperatures ranged from -3.7 to $37.2^{\circ} \mathrm{C}$ with an average of $182 \mathrm{~mm}$ of total rainfall across the two sites. The thirty-year normal for rainfall from May to September (1971-2000) in Winnipeg is $354 \mathrm{~mm}$ (Environment Canada, 2012). 
Samples were shipped from Manitoba to Alberta in an ice packed cooler on the same day they were collected. Samples were stored at $4^{\circ} \mathrm{C}$ and analyzed within 7 days by the Environmental Analytical Services department of Alberta Innovates Technology Futures (AITF), Edmonton, Alberta. Environmental Analytical Services is fully accredited by the Canadian Association for Laboratories Accreditation through the Standards Council of Canada.

Samples were analyzed for 31 herbicides, 7 insecticides and 5 fungicides currently being used in Manitoba agriculture, and 6 herbicide metabolites. As part of QA/QC protocols, for every batch of 11 samples, a laboratory blank was included, and a standard curve was run for calibration. Deuterated surrogates were added to water samples to determine percent recovery. All compounds were identified and quantified using retention times and compound specific ions of specific mass and charge. Minimum detection limits for the chemicals analyzed ranged from 0.005 to $1.0 \mu \mathrm{g} / \mathrm{L}$. For chemicals that had concentrations below the method detection limit, chemical concentrations were estimated as long as the chemical met the identification criteria.

The AITF method IE025MTH was used for the analyses of glyphosate, AMPA, and glufosinate in water. Briefly, samples were concentrated down to $500 \mu \mathrm{L}$ under nitrogen. Samples were then derivatized by adding $50 \mu \mathrm{L}$ of sample to $1.6 \mathrm{~mL}$ of $2: 1$ trifluoroacetic anhydride (TFAA): 2,2,3,3,4,4,4-heptafluoro-1-butanol (HFB) kept at $-60^{\circ} \mathrm{C}$. Following addition of sample, vials were capped and warmed to $90^{\circ} \mathrm{C}$ and held at that temperature for 1 hour. After one hour, samples were cooled to $40^{\circ} \mathrm{C}$ and evaporated to dryness under nitrogen. Samples were then re- 
dissolved in $100 \mu \mathrm{L}$ ethyl acetate. Quantification was carried out on a Varian 2200 GC/Iontrap mass spectrometer with a Varian 3400 autosampler and a DB-5 30m column.

The AITF method PESTE-EM443 was used for the analyses of the other chemicals (pesticides and herbicide metabolites) in water. Briefly, after acidification with phosphoric acid to a $\mathrm{pH}$ of 2 , samples were extracted using liquid-liquid partitioning with methylene chloride. After drying the samples through acidified sodium sulphate, the volume of each extract was reduced to about $300 \mu 1$ under nitrogen gas. Diazomethane was used to esterize acidic compounds in the extract. A Varian 2200 GC/Iontrap mass spectrometer with a Varian 3400 autosampler and a DB-5 30m column was used to analyze the extract (final volume $250 \mu \mathrm{l}$ ).

Estimates of pesticide use. The Manitoba Agricultural Services Corporation database contains data on the formulated pesticide products used on areas seeded to crops in each of the 1,124 townships with agricultural land in Manitoba (Wilson, 2012). Each township is 36 square miles or $93.2 \mathrm{~km}^{2}$, but the area of cropland in townships varies. The total mass of pesticides used in the nine townships adjacent to Winnipeg $\left(837 \mathrm{~km}^{2}\right)$ and in all townships with agricultural land in Manitoba $\left(104,532 \mathrm{~km}^{2}\right)$ was calculated by multiplying the area of the crop grown in each township by the maximum recommended rate of the pesticide active ingredient(s) applied to that crop. Maximum recommended field rates were obtained from the Manitoba Field Crop Protection Guide (2006) and it was assumed that the reported formulated pesticide product was only used once on the reported crop. Pesticide use estimates by Brimble et al. (2005) and by Cessna et al. (2010) also assumed one application. The masses of pesticides applied were calculated for each of years 2004, 2005 and 2006, which are the most recent three-years of data 
available prior to 2010-2011 when the bulk deposition samples were collected. The 2004-2006 data were averaged.

Winnipeg is located in township 11 range 03 east in which there is no reported agricultural pesticide use. For the pesticides detected in the study, urban use was estimated from Welch (2011) who summarized recorded pesticide use records in 2011 for $60 \%$ of the post-secondary institutions, $57 \%$ of the school divisions, $32 \%$ of the golf courses in the city. We adjusted the values in Welch (2011) to provide for a measure of pesticide use city-wide by assuming that the remaining $40 \%$ of the post-secondary institutions, $53 \%$ of the school divisions, $68 \%$ of the golf courses in the city applied pesticides at the same rate.

The masses of pesticides used in and around Winnipeg were combined to provide for a total measure of nearby pesticide use. Between 2004-2006 and 2010-2011 the area seeded to canola $(+40 \%)$, soybeans $(+83 \%)$ and corn $(+157 \%)$ around Winnipeg increased (Manitoba Agricultural Services Corporation 2013). These were likely glyphosate-resistant and glufosinate-resistant crop varieties, so increased glyphosate and glufosinate use would be expected but data was not adjusted for this. The increased acreages devoted to canola, soybeans and corn was mainly achieved by an overall increase in agricultural cropland around Winnipeg $(+14 \%)$ and a decrease in areas seeded to wheat (-18\%). The area seeded to canola, soybeans and corn around Winnipeg was 7\% smaller in 2011 than 2010, and hence the amounts of glyphosate and glufosinate applied in 2011 would have been relatively similar, or somewhat smaller, than the amounts of these herbicides applied in 2010. 


\section{Results and Discussion}

Fourteen herbicides, five herbicide metabolites, two insecticides and two fungicides were detected (Table 1). $98.5 \%$ of the samples contained more than one chemical and $4.4 \%$ of the samples had 13 chemicals (Figure 1), which was the maximum number of chemicals detected in a sample. Glyphosate and ten other herbicides were detected at each site in both years (Table 1). The average seasonal deposition of these eleven herbicides across two years was positively associated with their amounts used both in and around Winnipeg $(\mathrm{r}=0.93, \mathrm{P}<0.001)$, their use on agricultural land around Winnipeg $(r=0.91, \mathrm{P}<0.001)$ and their use on agricultural land province wide $(\mathrm{r}=0.86, \mathrm{P}<0.001)$. Excluding glyphosate, whose agricultural use around Winnipeg far exceeded that of any other pesticides (Figure 2), the average seasonal deposition of the other ten herbicides was also significantly positively correlated with the amount of herbicides applied both in and around Winnipeg $(\mathrm{r}=0.90, \mathrm{P}<0.001)$ but to a lesser extent with agricultural herbicide use around Winnipeg ( $\mathrm{r}=0.63, \mathrm{P}=0.05)$, and not with agricultural herbicide use province wide $(\mathrm{p}=0.23)$. 
Table 1. Maximum detection limits (MDL) and summary data of the detections of chemicals at each site year. For each year, data for Ridge (left) and Vital (right) are displayed in the same column and separated by a dash (-).

\begin{tabular}{|c|c|c|c|c|c|c|c|c|}
\hline Pesticide & $\begin{array}{l}\text { MDL } \\
(\mu \mathrm{g} / \mathrm{L})\end{array}$ & \multicolumn{3}{|c|}{$\begin{array}{c}\text { Total seasonal detection } \\
\qquad\left(\mu \mathrm{g} / \mathrm{m}^{2}\right)\end{array}$} & \multicolumn{2}{|c|}{$\begin{array}{l}\text { Detection frequency } \\
\text { (\% of samples) }\end{array}$} & \multicolumn{2}{|c|}{$\begin{array}{l}\text { Maximum weekly concentration } \\
\qquad(\mu \mathrm{g} / \mathrm{L})\end{array}$} \\
\hline \multicolumn{9}{|l|}{ Herbicides } \\
\hline 2,4-DB & 0.005 & ND - ND & 0.38 & - ND & ND - ND & $6-0$ & ND - ND & $0.01-\mathrm{ND}$ \\
\hline Atrazine & 0.005 & $6.96-13.06$ & 5.77 & -4.75 & 47-38 & $44-47$ & $0.04-0.09$ & $0.22-0.22$ \\
\hline Bentazon & 0.010 & $0.42-0.47$ & 0.11 & -0.12 & $6-6$ & $11-12$ & $0.02-0.02$ & $0.02-0.03$ \\
\hline Dicamba & 0.005 & $2.80-6.33$ & 6.26 & - 5.01 & $76-88$ & $78-88$ & $0.07-0.09$ & $0.24-0.38$ \\
\hline Dichlorprop & 0.005 & $0.20-\mathrm{ND}$ & 0.04 & - 0.02 & $6-\mathrm{ND}$ & $11-6$ & $0.02-\mathrm{ND}$ & $0.01-<0.005$ \\
\hline Fluroxypyr & 0.040 & $0.18-0.15$ & 0.96 & -0.44 & $6-6$ & $28-29$ & $0.02-0.01$ & $0.05-0.04$ \\
\hline Glyphosate & 0.200 & $41.27-80.05$ & 297.42 & -355.59 & $61-71$ & $94-100$ & $0.99-0.80$ & $16.91-11.81$ \\
\hline MCPA & 0.005 & $10.31-17.44$ & 21.40 & -9.66 & $53-69$ & $89-82$ & $0.21-0.16$ & $1.11-0.50$ \\
\hline Mecoprop & 0.005 & $9.3-21.60$ & 30.01 & - 18.49 & $76-94$ & $100-100$ & $0.12-0.23$ & $0.72-1.02$ \\
\hline $\mathrm{ClC}_{6} \mathrm{H}_{3}\left(\mathrm{CH}_{3}\right) \mathrm{OH}^{1}$ & 0.010 & ND - ND & 0.59 & -0.02 & ND - ND & $6-6$ & ND - ND & $0.04-0.02$ \\
\hline AMPA $^{1}$ & 0.500 & $27.39-22.29$ & 4.67 & -0.80 & $6-6$ & $17-18$ & $0.89-0.70$ & $1.58-1.12$ \\
\hline DIA $^{1}$ & 0.050 & ND - ND & 0.23 & - 0.38 & ND - ND & $6-6$ & ND - ND & $0.02-0.03$ \\
\hline $\mathrm{DEA}^{1}$ & 0.050 & $2.02-4.89$ & 1.15 & - 1.08 & $12-6$ & $17-24$ & $0.02-0.04$ & $0.05-0.04$ \\
\hline \multicolumn{9}{|l|}{ Insecticides } \\
\hline Chlorpyrifos & 0.005 & ND - 0.08 & ND & - 0.30 & ND - 6 & ND - 12 & ND $-<0.005$ & ND - 0.01 \\
\hline Diazinon & 0.005 & ND - 2.97 & ND & - ND & ND - 13 & ND - ND & ND - 0.09 & ND - ND \\
\hline \multicolumn{9}{|l|}{ Fungicides } \\
\hline Chlorothalonil & 0.005 & $0.84-0.74$ & 0.01 & $-\quad N D$ & $12-6$ & $6-N D$ & $0.01-0.02$ & $<0.005-\mathrm{ND}$ \\
\hline Propiconazole & 0.050 & $0.54-0.56$ & 0.44 & $\begin{array}{l}-\quad 0.42 \\
\end{array}$ & $6-6$ & $11-12$ & $0.05-0.02$ & $0.09-0.08$ \\
\hline
\end{tabular}

${ }^{1}$ 2,4-DCP = 2,4-dichlorophenol, $\mathrm{ClC}_{6} \mathrm{H}_{3}\left(\mathrm{CH}_{3}\right) \mathrm{OH}=$ 4-chloro-2- methylphenol, DIA = desisopropyl atrazine, DEA = desethyl atrazine. 


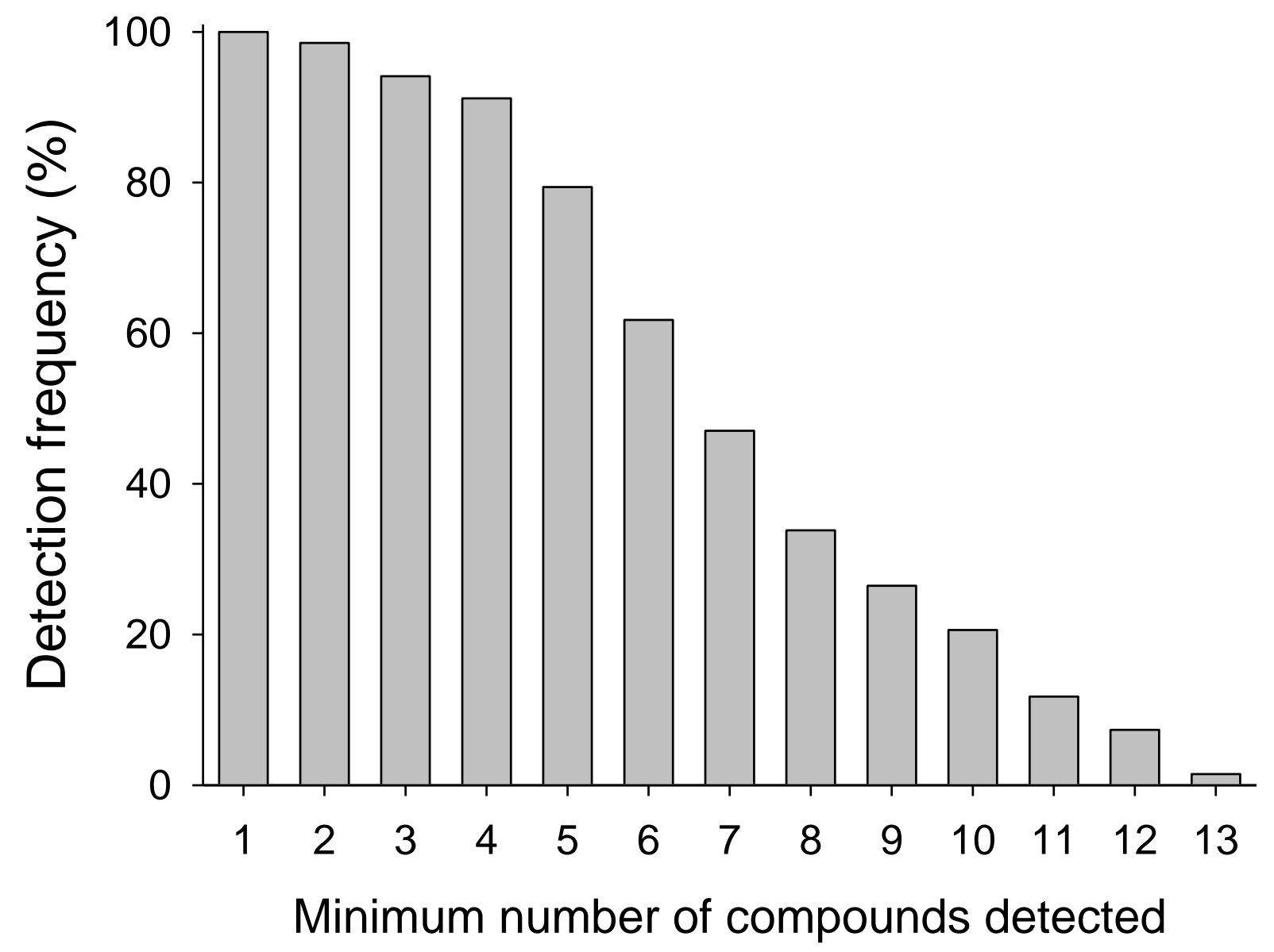

Figure 1. Summary of the minimum number of compounds detected in weekly bulk deposition samples collected across two years and two sites in Winnipeg. In total, fourteen herbicides, five herbicide metabolites, two insecticides, and two fungicides were detected. 


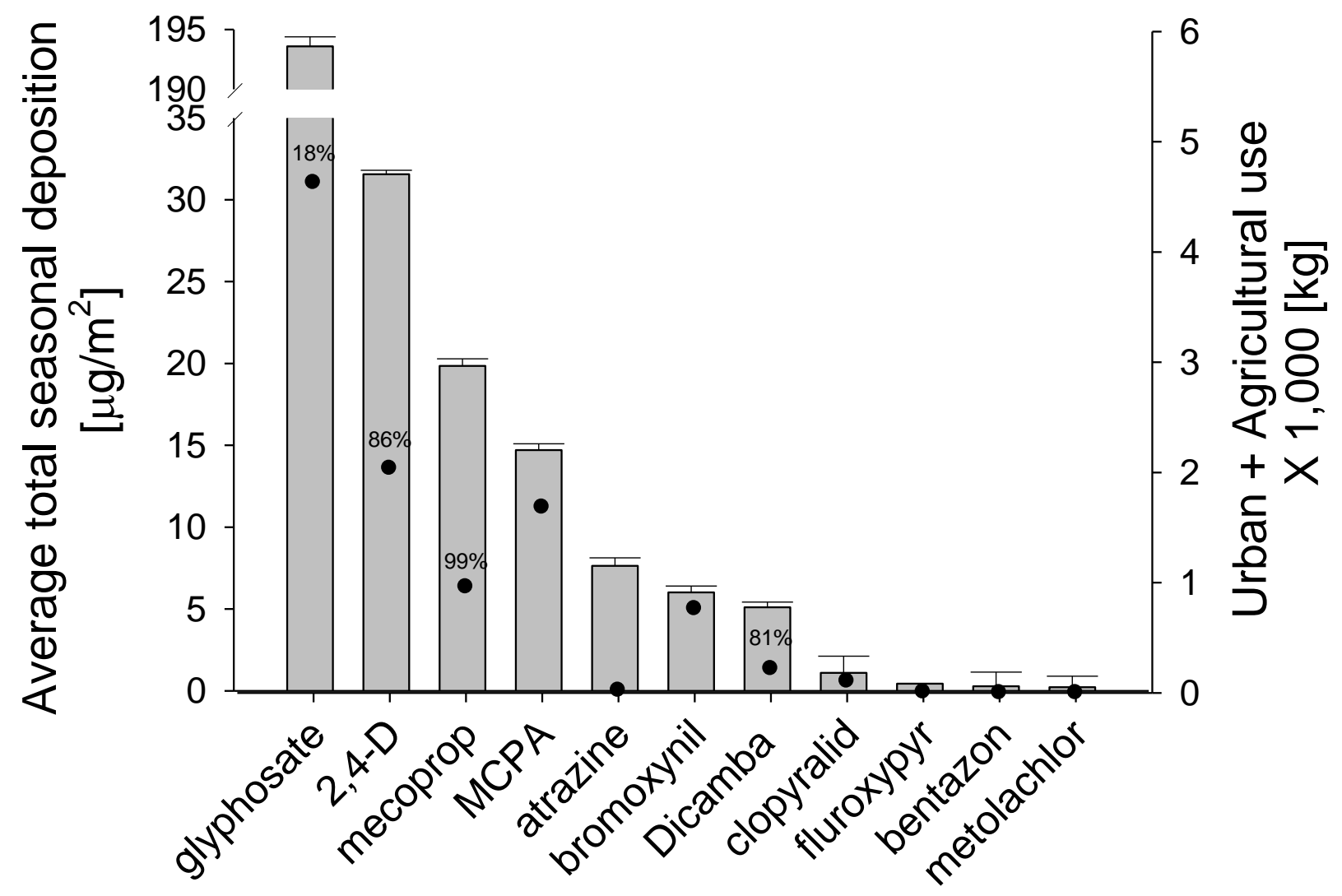

Figure 2. Averaged total seasonal bulk deposition of selected herbicides detected from May to September, 2010 and 2011 at two sites in Winnipeg (grey bars). The masses of the herbicides used in the city and on agricultural land surrounding Winnipeg is also indicated (black dots). Percentages refer to the amount of herbicides applied in the city, out of the total mass of the herbicide applied in the city and on agricultural land surrounding Winnipeg. If no percentage is indicated, the herbicide had no reported urban use. 
Glyphosate was detected in $81 \%$ of the samples (Table 2) and accounted for $65 \%$ of the total pesticide deposition across the two years. There were eight weeks without rainfall across the two years during which glyphosate was detected in each week with its deposition ranging from 0.2 to $16.9 \mu \mathrm{g} / \mathrm{m}^{2} /$ week. Glyphosate was detected in $70 \%$ of the weeks with rainfall with an average deposition of $15 \mu \mathrm{g} / \mathrm{m}^{2} /$ week. Dry deposition was an important component of total glyphosate deposition in weeks without and with rainfall because, given its high Koc value $(21,699 \mathrm{mg} / \mathrm{g})$ and low vapour pressure $\left(0.0131 \mathrm{mPa}\right.$ at $\left.25^{\circ} \mathrm{C}\right)$ (University of Hertfordshire, 2013), glyphosate tends to be associated with particulate matter (dust) in the atmosphere rather than the vapourphase (Chang et al. 2011). There was no significant correlation between the weekly amount of rainfall and weekly glyphosate deposition, most likely because glyphosate bulk deposition results from dust particles are washed out of the atmosphere by rain, rather than the herbicide being dissolved in rain (Humphries et al., 2005).

Total seasonal deposits of glyphosate ranged from $41 \mu \mathrm{g} / \mathrm{m}^{2}$ (Ridge) to $80 \mu \mathrm{g} / \mathrm{m}^{2}$ (Vital) in 2010 and from 297 (Ridge) to $356 \mu \mathrm{g} / \mathrm{m}^{2}$ (Vital) in 2011 (Table 1). The total seasonal deposition of all other chemicals combined ranged from $90 \mu \mathrm{g} / \mathrm{m}^{2}$ (Ridge) to $134 \mu \mathrm{g} / \mathrm{m}^{2}$ (Vital) in 2010 and from $77 \mu \mathrm{g} / \mathrm{m}^{2}$ (Vital) to 120 (Ridge) in 2011. Thus, glyphosate accounted for $31 \%$ (Ridge) and $37 \%$ (Vital) of the total seasonal deposition in 2010, but for 71\% (Ridge) and 82\% (Vital) in 2011. 2011 was a drier year and greater particulate transport is probably the reason for the more frequent and larger masses of glyphosate detected throughout the 2011 than 2010 season (Figure 3). Agricultural land in the prairies is more prone to wind erosion than agricultural land in other regions of Canada, and wind erosion and atmospheric particulate transport occurs particularly in drier years (Coote et al. 1981, Lobb et al. 2010). Following agricultural application, most 
glyphosate residues are retained in the soil surface layer due to its strong sorption by soil (AlRajab et al. 2008, Bergström et al. 2011) and hence glyphosate is prone to be transported by wind-eroded sediments. For herbicides applied to the soil surface at a Prairie agricultural site, Larney et al. (1999) demonstrated that on average $4.5 \%$ of that applied could be detected in eroded sediment. 
Table 2. Pesticide active ingredients registered for use in Manitoba agriculture in 2010 and 2011 and their frequency of detection in all bulk deposition samples of 2010 and 2011 combined. Pesticides with an asterisk (*) were detected at each site and in both years. Area refers to the estimated area of land receiving at least one annual application as estimated from available averaged data that were reported by Manitoba producers in 2004, 2005 and 2006 (Wilson 2013). The rank of the area applied (\#) refers to the relative rank out of all 112 pesticide active ingredient for which data on the area applied were available.

\begin{tabular}{|c|c|c|c|c|c|c|c|c|c|}
\hline \multicolumn{4}{|c|}{ DETECTED } & \multicolumn{6}{|c|}{ NOT DETECTED } \\
\hline Pesticide (Type) & $\begin{array}{c}\text { Detect } \\
(\%)\end{array}$ & $\begin{array}{c}\text { Area } \\
\text { X 10 } \\
\text { (ha) }\end{array}$ & $\#$ & Pesticide (Type) & $\begin{array}{c}\text { Area } \\
\text { X 10 } \\
\text { (ha) }\end{array}$ & \# & Pesticide (Type) & $\begin{array}{c}\text { Area } \\
\text { X } 10^{3} \\
\text { (ha) }\end{array}$ & $\#$ \\
\hline $\operatorname{MCPA}(\mathrm{H})^{*}$ & $74 \%$ & 1,140 & 1 & Fenoxaprop (H) & 375 & 5 & Endosulfan (I) & $<1$ & 80 \\
\hline Glyphosate $(\mathrm{H})^{*}$ & $81 \%$ & 679 & 2 & Glufosinate $(\mathrm{H})$ & 365 & 6 & Phorate (I) & $<1$ & 90 \\
\hline Bromoxynil $(\mathrm{H})^{*}$ & $56 \%$ & 577 & 3 & Clodinafop (H) & 221 & 12 & $\mathrm{MCPB}(\mathrm{H})$ & $<0.1$ & 93 \\
\hline Propiconazole $(\mathrm{F}) *$ & $9 \%$ & 387 & 4 & Imazethapyr (H) & 170 & 14 & Simazine $(\mathrm{H})$ & $<0.1$ & 102 \\
\hline $2,4-\mathrm{D}(\mathrm{H})^{*}$ & $97 \%$ & 326 & 8 & $\operatorname{Imazamox}(\mathrm{H})$ & 138 & 18 & Methomyl (I) & $<0.1$ & 104 \\
\hline Clopyralid $(\mathrm{H})^{*}$ & $12 \%$ & 176 & 13 & Iprodione $(\mathrm{F})$ & 130 & 19 & Picloram $(\mathrm{H})$ & $<0.1$ & 105 \\
\hline Fluroxypyr $(\mathrm{H}) *$ & $18 \%$ & 163 & 15 & Imazamethabenz $(\mathrm{H})$ & 105 & 22 & Triclopyr $(\mathrm{H})^{1}$ & 0 & $\mathrm{~N} / \mathrm{A}$ \\
\hline $\operatorname{Dicamba}(\mathrm{H})^{*}$ & $82 \%$ & 122 & 21 & Ethalfluralin $(\mathrm{H})$ & 81 & 26 & Thiamethoxam $(\mathrm{I})^{2}$ & - & $\mathrm{N} / \mathrm{A}$ \\
\hline 2,4-DP $(\mathrm{H})$ & $6 \%$ & 91 & 24 & Metribuzin $(\mathrm{H})$ & 26 & 39 & & & \\
\hline Bentazon $(\mathrm{H})^{*}$ & $9 \%$ & 67 & 27 & Quizalofop (H) & 21 & 42 & & & \\
\hline Mecoprop $(\mathrm{H})^{*}$ & $93 \%$ & 61 & 29 & Metalaxyl (F) & 16 & 45 & & & \\
\hline Trifluralin (H) & $3 \%$ & 36 & 35 & Dimethoate (I) & 12 & 50 & & & \\
\hline Atrazine $(\mathrm{H})^{*}$ & $44 \%$ & 15 & 46 & Quinclorac (H) & $<10$ & 55 & & & \\
\hline Chlorothalonil (F) & $6 \%$ & 10 & 53 & Fluazifop $(\mathrm{H})$ & $<10$ & 58 & & & \\
\hline Chlorpyrifos (I) & $4 \%$ & $<10$ & 59 & Linuron $(\mathrm{H})$ & $<10$ & 60 & & & \\
\hline $2,4-\mathrm{DB}(\mathrm{H})$ & $1 \%$ & $<1$ & 87 & Triallate $(\mathrm{H})$ & $<10$ & 66 & & & \\
\hline Metolachlor (H) & $12 \%$ & $<0.1$ & 94 & Carbathiin $(\mathrm{F})$ & $<10$ & 69 & & & \\
\hline Diazinon (I) & $3 \%$ & $<0.1$ & 100 & & & & & & \\
\hline
\end{tabular}

${ }^{\mathrm{I}}$ The Crop Protection Guide for Western Canada listed triclopyr as a registered herbicide for use in Manitoba in 2004,2005 and 2006 but no use was reported in these years. ${ }^{2}$ Thiamethoxam was not listed as a registered insecticide for use in Manitoba in 2004,2005 or 2006. 


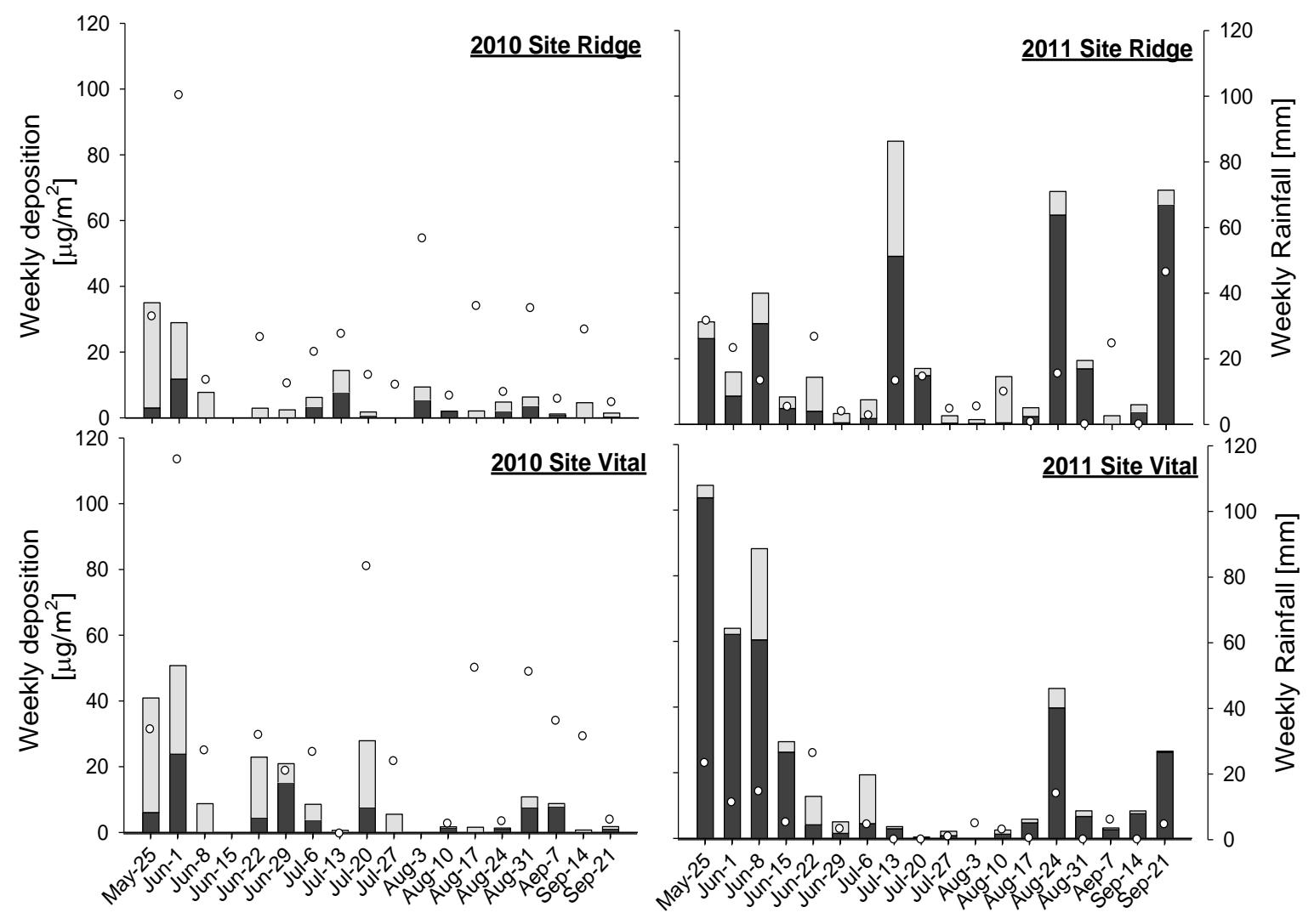

Figure 3. Weekly bulk deposition of glyphosate (dark bars) and all other compounds combined (light bars) at sites Ridge and Vital in 2010 and 2011. Weekly rainfall is indicated by open circles. Other compounds were thirteen herbicides, five herbicide metabolites, two insecticides and two fungicides, some of which were more frequently detected than others (Table 1). 
Aminomethylphosphonic acid (AMPA), the primary metabolite of glyphosate resulting from microbial metabolism or photochemical reactions (Carey et al. 2008), was detected in all four site-years but less frequently than glyphosate. AMPA was detected in only one week in 2010 and in three weeks in 2011 (Table 1). Humphries et al. (2005) did not detect AMPA in 28 bulk deposition samples collected across three rural sites in the Province of Alberta, and attributed these results to the relatively rapid degradation of AMPA in the atmosphere and the higher detection limit of AMPA relative to glyphosate. In Chang et al. (2011), the detection limit of AMPA was smaller than that of glyphosate and both compounds were detected in the same frequency.

2,4-D, mecoprop, dicamba, MCPA and bromoxynil were also detected in more than half of the samples collected across the two years (Table 2). 4-chloro-2-methylphenol, a metabolite of both mecoprop and MCPA, and 2,4-dichlorophenol, a metabolite of 2,4-D, were also detected but not consistently across years (Table1). All five herbicides have a vapor pressure $<10^{-6} \mathrm{~Pa}$ and a Henry Law constant $<1 \mathrm{~Pa} \mathrm{~m}^{3} \mathrm{~mol}^{-1}$ (University of Hertfordshire, 2013). Given these characteristics, processes such as dry deposition, rain removal of particulates and herbicide vapor transfer into raindrops could all contribute to the removal of 2,4-D, mecoprop, dicamba, MCPA and bromoxynil from the atmosphere (Majewski and Capel 1995, page 147).

2,4-D, mecoprop, dicamba, MCPA and bromoxynil are post-emergent herbicides and hence used in the Prairies mainly from May to July, which is when the herbicides are predominantly detected in air and deposition samples at rural sites (Waite et al, 2005, Messing et al. 2011). For example, for a rural site in Manitoba, bromoxynil, 2,4-D and MCPA were always detected in the 
weekly bulk deposition samples collected from late-May to late-July, but these herbicides were detected in 0\% (bromoxynil), 29\% (2,4-D) and 57\% (MCPA) of the weekly samples collected from August to mid-September. In the current study, MCPA and particularly bromoxynil were also less frequently detected in August and September than from May to July (Table 3), reflecting the decreased MCPA and bromoxynil use in August and September on agricultural land around Winnipeg. Messing et al. (2011) detected the five herbicides in the following decreasing frequency at the rural site: $\operatorname{MCPA}(76 \%)>2,4-\mathrm{D}(65 \%)>$ bromoxynil $(53 \%)>$ dicamba $(41 \%)>$ mecoprop $(6 \%)$. In contrast, in the current study, the frequency of detection in the city decreased from 2,4-D $(97 \%)>$ mecoprop $(93 \%)>$ dicamba $(82 \%)>$ MCPA $(74 \%)>$ bromoxynil (56\%). Bromoxynil and MCPA have no reported use within city-limits (Figure 2) but 2,4-D, mecoprop and dicamba are commonly applied within city limits (Figure 2). 2,4-D, mecoprop and dicamba were consistently detected throughout May to September in 2010 and 2011 (Table 3), suggesting that urban applications influenced the total seasonal bulk deposition of these herbicides in Winnipeg. This agrees well with Todd and Struger (2014) who concluded that the presence of 2,4-D, mecoprop and dicamba in urban streams in the province of Ontario was most likely due to urban herbicide use as 2,4-D, mecoprop and dicamba concentrations in streams decreased up to $92 \%$ after the provincial government banned the sale and use of pesticides for cosmetic purposes. 
Table 3. Average weekly deposition and frequency of detection of five post-emergent herbicides in the first half and second half of the season in 2010 and 2011. Weekly bulk deposition samples were collected for 18 weeks from May 18 to September 21 during 2010 and 2011. In 2010, data was split by "prior to mid-July" and "after mid-July" as these times showed clear differences in the frequencies of detections for bromoxynil and MCPA. In 2011, data was split by "prior to early-August" and "after early-August" as these times showed clear differences in the frequencies of detections for bromoxynil, and to a lesser extent for MCPA. The bulk of the post-emergent herbicides are typically applied on Prairie agricultural land from May to July, although if the start of the growing season has been delayed due to less than optimum weather conditions, these bulk applications may extent into August.

\begin{tabular}{|c|c|c|c|c|c|c|c|c|}
\hline & \multicolumn{2}{|c|}{ Prior to mid-July 2010} & \multicolumn{2}{|c|}{ After mid-July 2010} & \multicolumn{2}{|c|}{ Prior to early-August 2011} & \multicolumn{2}{|c|}{ After early-August 2011} \\
\hline Herbicide & $\begin{array}{c}\text { Deposition } \\
{\left[\mu \mathrm{g} \mathrm{m}^{-2}\right]}\end{array}$ & $\begin{array}{c}\text { Frequency } \\
{[\%]}\end{array}$ & $\begin{array}{c}\text { Deposition } \\
{\left[\mu \mathrm{g} \mathrm{m}^{-2}\right]}\end{array}$ & $\begin{array}{c}\text { Frequency } \\
{[\%]}\end{array}$ & $\begin{array}{c}\text { Deposition } \\
{\left[\mu \mathrm{g} \mathrm{m}^{-2}\right]}\end{array}$ & $\begin{array}{c}\text { Frequency } \\
{[\%]}\end{array}$ & $\begin{array}{c}\text { Deposition } \\
{\left[\mu \mathrm{g} \mathrm{m}^{-2}\right]}\end{array}$ & $\begin{array}{c}\text { Frequency } \\
{[\%]}\end{array}$ \\
\hline Bromoxynil & 0.87 & 100 & $<0.01$ & 6 & 0.48 & 90 & $<0.01$ & 14 \\
\hline MCPA & 1.71 & 100 & 0.02 & 22 & 1.39 & 100 & 0.14 & 64 \\
\hline $2,4-\mathrm{D}$ & 2.49 & 100 & 0.81 & 89 & 2.14 & 100 & 1.93 & 100 \\
\hline Mecoprop & 1.39 & 88 & 0.48 & 83 & 1.74 & 100 & 0.86 & 100 \\
\hline Dicamba & 0.41 & 81 & 0.14 & 89 & 0.36 & 71 & 0.26 & 100 \\
\hline
\end{tabular}


There was a positive significant correlation between the weekly amount of rainfall and weekly deposition for both 2,4-D $(r=0.33, \mathrm{P}<0.05)$ and bromoxynil $(\mathrm{r}=0.52, \mathrm{P}<0.01)$ but not for MCPA $(\mathrm{P}=0.15)$, dicamba $(\mathrm{P}=0.14)$ or mecoprop $(\mathrm{P}=0.20)$. 2,4-D, mecoprop and dicamba were always detected in the eight weeks without rainfall resulting in a total dry deposition during these weeks of $6.39 \mu \mathrm{g} \mathrm{m}^{-2}$ for 2,4-D, $2.10 \mu \mathrm{g} \mathrm{m}^{-2}$ for mecoprop and $0.89 \mu \mathrm{g} \mathrm{m}^{-2}$ for dicamba. MCPA and bromoxynil were detected in four of the weeks that had no rainfall. Other studies have shown particulate transport to be important for the movement of 2,4-D, mecoprop, dicamba, MCPA and bromoxynil (Waite et al. 2004, Messing et al. 2013). For a rural site in Manitoba, dry deposition accounted for $15-21 \%$ of the total bulk deposition of 2,4-D, dicamba, MCPA and bromoxynil from May to July and for 50\% of that for mecoprop (Messing et al. 2013).

Herbicides other than those mentioned above were, but for one exception, were detected in less than $20 \%$ of the samples (Table 2). The exception was atrazine, which was detected in 37 to $47 \%$ of the samples depending on the site (Table 1). Atrazine is not widely used in Manitoba agriculture (Table 2) but it can be transported with particulate matter hundreds of kilometers from where it is applied (Calamari et al. 2000, Thurman and Cromwell 2000). Of the two atrazine metabolites examined, desethylatrazine (DEA) was more frequently detected than desisopropylatrazine (DIA) in our bulk deposition samples (Table 1), which is similar to that found in other studies (Goolsby et al. 1997, Van Dijk et al. 1999, Schribner et al. 2005). DEA is formed more readily than DIA in both soil and the atmosphere, and DEA is also more stable than DIA in the environment (Skipper and Volk 1972, Adams and Thurman 1991, Meijers et al. 1995, Schribner et al. 2005). 
Two fungicides were detected, chlorothalonil and propiconazole, both of which are applied in Winnipeg primarily on golf courses. Propiconazole is widely applied in Manitoba agriculture, but the agricultural use of chlorothalonil is relatively low (Table 2), with no reported use of chlorothalonil around Winnipeg. Based on our estimates, the annual mass of propiconazole used in Winnipeg is 14-fold larger than that typically used on agricultural land surrounding Winnipeg. Given that the two fungicides were detected in approximately the same frequency, $6 \%$ (chlorothalonil) and 9\% (propiconazole) (Table 2), urban fungicide use is likely a main contributor to the deposition of these two fungicides in Winnipeg.

Two insecticides were occasionally detected (Table 1). Chlorpyrifos is used in Manitoba agriculture (Table 2) including on agricultural land around Winnipeg but not in the city. Diazinon was detected in St. Vital in 2010 (Table 1), despite no reported use of the insecticide on agricultural land surrounding Winnipeg or in the city. Diazinon is banned for use by the public and has restricted agricultural use but has been previously detected in air samples in the Canadian prairies presumably as a result of long-range transport from agricultural land where it was applied (Raina et al., 2010).

The concentrations of the individual pesticides detected in the weekly bulk deposition samples varied from $<0.005 \mu \mathrm{g} / \mathrm{L}$ for some pesticides to $16.91 \mu \mathrm{g} / \mathrm{L}$ for glyphosate (Table 1 ). None of the concentrations of individual pesticides detected in this study exceeded the acute 48 hour median effective concentration (EC50) for Daphnia magna, which is a keystone species and bioindicator of good environmental health. For eleven pesticides detected in this study, various Canadian water quality guidelines have been developed with set concentrations. The individual 
concentrations of the pesticides detected in the deposition samples were generally well below their respective Canadian water quality guidelines, but there were a few exceptions (Table 4). The Canadian Drinking Water Quality Guidelines for fresh water were exceeded in case of chlorothalonil and chlorpyrifos but in a small percentage of the samples (1-3\%). Of the total samples collected, the Canadian Water Quality Guidelines for irrigation water were frequently exceeded for both dicamba (75\%) and MCPA (49\%). Irrigation water quality guidelines have been establish for agricultural purposes and plants in urban gardens can have higher sensitivities to pesticides than agricultural crops (Boutin et al., 2004). Hill et al. (2001) irrigated dry beans and tomatoes at the three to four leaf stage with herbicides mixtures (dicamba, MCPA, 2,4-D, and bromoxynil) in concentrations equal to that detected in rainfall at rural sites in the Prairies. The treated plant showed a range of poorer growth indicators, relative to plants exposed to irrigation water free of herbicides. The impact of dicamba and MCPA deposition on plants in urban gardens is currently unknown as is the absorption of these herbicides into parts of the produce that may be consumed by city residents. 
Table 4. Maximum weekly concentration of individual pesticides detected in bulk deposition across two years. As a comparison, the Canadian water quality guidelines (Canadian Council of Ministers of the Environment, 2013) and the acute 48 hour median effective concentration (EC50) for risk indicator species Daphnia Magna (University of Hertfordshire 2013) is also indicated. Percentages in bold refer to the \% of samples exceeding the guidelines or risk indicator. Note that EC50 is given in $\mathrm{mg} / \mathrm{L}$ and all other values are in $\mu \mathrm{g} / \mathrm{L}$. A range of other pesticides were detected, but these pesticides are not included in the table because they lack Canadian water quality guidelines and their EC50 Daphnia Magna values were greater than the concentrations detected.

\begin{tabular}{|c|c|c|c|c|c|c|}
\hline Pesticide & $\begin{array}{c}\text { Max. conc. } \\
\text { detected } \\
(\mu \mathrm{g} / \mathrm{L})\end{array}$ & $\begin{array}{c}\text { Drinking water } \\
(\mu \mathrm{g} / \mathrm{L}) \\
\end{array}$ & $\begin{array}{c}\text { Livestock } \\
\text { water }^{2} \\
(\mu \mathrm{g} / \mathrm{L}) \\
\end{array}$ & $\begin{array}{c}\text { Irrigation } \\
\text { water }^{3} \\
(\mu \mathrm{g} / \mathrm{L}) \\
\end{array}$ & $\begin{array}{c}\text { Fresh water }^{4} \\
(\mu \mathrm{g} / \mathrm{L}) \\
\end{array}$ & $\begin{array}{c}\text { Daphnia } \\
\text { Magna, EC50 } \\
(\mathrm{mg} / \mathrm{L}) \\
\end{array}$ \\
\hline $2,4-\mathrm{D}$ & 1.7 & 100 & 100 & N/A & 4 & 100 \\
\hline Atrazine & 0.22 & 5 & 5 & 10 & 1.8 & 85 \\
\hline Bromoxynil & 0.29 & 5 & 11 & 0.33 & 5.0 & 12.5 \\
\hline Chlorothalonil & 0.002 & N/A & 170 & 5.8 & $0.18(1 \%)$ & 0.1 \\
\hline Chlorpyrifos & 0.01 & 90 & 24 & N/A & $0.002(3 \%)^{5}$ & 0.0001 \\
\hline Dicamba & 0.38 & 120 & 122 & $0.006(75 \%)$ & 10 & $>41$ \\
\hline Glyphosate & 16.9 & 280 & 280 & N/A & $800^{5}$ & 40 \\
\hline MCPA & 1.1 & 100 & 25 & $0.025(49 \%)$ & 2.6 & $>190$ \\
\hline Metolachlor & 0.02 & 50 & 50 & 28 & 7.8 & 23.5 \\
\hline Trifluralin & 0.005 & N/A & 45 & N/A & 0.2 & 0.245 \\
\hline Diazinon & 0.09 & 20 & N/A & N/A & N/A & 0.001 \\
\hline
\end{tabular}

${ }^{\mathrm{I}}$ Guidelines for Canadian Drinking Water Quality, ${ }^{2}$ Canadian Water Quality Guidelines for the Protection of Agriculture for livestock water, ${ }^{3}$ Canadian Water Quality Guidelines for the Protection of Agriculture for irrigation water, ${ }^{4}$ Canadian Water Quality guidelines for the Protection of Aquatic Life. 
More than twenty pesticides with known uses in Manitoba agriculture were not detected in this study (Table 2). This included herbicides fenoxaprop and glufosinate that are among the most widely applied pesticides in Manitoba (Table 2). Pesticide residues become airborne through application drift, volatilization from plant, land and water surfaces, or by being attached to winderoded soil (Grover et al. 1985; Coupe et al., 2000; Larney et al., 1999). Both fenoxaprop and glufosinate are rapidly degraded in Prairie and other soils (Smith 1985, Smith 1988, Smith and Belyk 1989, Xiaoxu et al. 2011, Sing et al. 2013) and hence post-volatilization losses and their attachment to wind-eroded soil are expected to be limited.

\section{Conclusion}

The city of Winnipeg (population 600,000) is surrounded by agriculture like many other cities and towns in the Prairie region of Canada that encompasses $\sim 527,000 \mathrm{~km}^{2}$ of agricultural land. Glyphosate is the most widely used agricultural pesticide in the Prairies and accounted for 65\% of the total pesticide deposition in the city between May 18 to September 21 in 2010 and 2011. Glyphosate deposition was more pronounced in the drier year (2011). None of glyphosate concentrations in rain exceeded any of the Canadian Water Quality Guidelines established for this herbicide. $27 \%$ of the total pesticide deposition was accounted for by 2,4-D, mecoprop, dicamba, MCPA and bromoxynil, which are five post-emergent herbicides widely used in agriculture in the Prairies. Urban application was the most likely reason to why 2,4-D, mecoprop and dicamba were more consistently detected in samples relative to MCPA and bromoxynil. The concentrations of dicamba and MCPA detected in rainfall frequently exceeded the Canadian Water Quality Guidelines set for irrigation water on agricultural crops, warranting further studies on whether herbicides in contaminated urban rain could be absorbed by garden plants and, if so, what would be the herbicide translocation to edible parts in garden produce. Eight other 
herbicides, two insecticides and two fungicides accounted for the remaining $8 \%$ of the total pesticide deposition over two years of which chlorothalonil and propiconazole were mainly from urban applications. Restrictions of the sale and use of pesticides within Prairie cities and towns could reduce the amounts of pesticides detected in bulk deposition in these urban environments, but pesticides applied on surrounding agricultural land would continue to contribute to non-point source pollution of pesticides in urban bulk deposition.

\section{Acknowledgements}

We gratefully acknowledge the Natural Sciences and Engineering Council of Canada (NSERC) for provided research funding to complete this study. Lindsey Andronak was also supported by a University of Manitoba Graduate Fellowship (UMGF). In addition, the authors also acknowledge Alberta Innovates Technology Futures for the commercial laboratory analysis and the field assistance of Paul Messing, Terri Ramm and Karin Rose.

\section{References}

Adams, C.D., Thurman, E.M. 1991. Formation and transport of deethylatrazine in the soil and vadose zone. Journal of Environmental Quality 20, 540-547.

Al-Rajab, A.J., Amella, S., Schiavon, M. 2008, Sorption and leaching of 14C-glyphosate in agricultural soils. Agron. Sustain. Dev. 28, 419-428.

Beckie, H. J., Harker, K. N., Hall, L. M., Warwick, S. I., Légère, A., Sikkema, P.H., Clayton, G.W., Thomas, A. G., Leeson, J.Y., Séguin-Swartz,G., Simard, M.-J. 2006. A decade of herbicide-resistant crops in Canada. Can. J. Plant Sci. 86, 1243-1264.

Bergström, L., Börjesson, E., Stenström, J. 2011. Laboratory and lysimeter studies of glyphosate and aminomethyl phosphonic acid in a sand and a clay Soil. Journal of Environmental Quality 40, 98-108.

Boutin C., Elmegaard N., Kjær C. 2004. Toxicity testing of fifteen non-crop plant species with six herbicides in a greenhouse experiment: Implications for risk assessment. Ecotoxicology 13, 349-369. 
Brimble, S., Bacchus, P., Caux P.-Y 2005. Pesticide Utilization in Canada: A compilation of Current Sales and Use Data. Environment Canada: Ottawa, ON.

Calamari, D., Jones, K., Kannan, K., Lecloux, A., Olsson, M., Thurman, M., Zannetti, P. 2000. Monitoring as an indicator of persistence and long-range transport. Pages 205 to 239 in Klečka, G., Boethling, B., Franklin, J., Grady, L., Graham, D., Howard, P.H., Kannan, K., Larson, R.J., Mackay,D., Muir, D., van de Meent, D. (eds). Evaluation of Persistence and Long-Range Transport of Organic Chemicals in the Environment. SETAC Press Pensacola, Florida, U.S.A.

Carey, S., Crk, T., Flaherty, C., Hurley, B., Hetrich, J., Moore, K., Thermes, S.C. 2008. Risks of glyphosate use to federally threatened California red-legged frog (Rana aurora draytonii). Pesticide Effects Determination. Environmental Fate and Effects Division Office of Pesticide Programs Washington, D.C. 20460.

Cessna, A.J., Sheedy, C., Farenhorst, A., McQueen, D.A.R. 2010. Pesticides. Pages 101-107 in Eilers, W., MacKay, R., Graham, L.and Lefebvre, A. (eds). Environmental Sustainability of Canadian Agriculture: Agri-Environmental Indicator Report Series - Report \#3. Agriculture and Agri-Food Canada, Ottawa, Ontario.

Chang F.C., Simcik M. F., Capel P. D. 2011. Occurrence and fate of the herbicide glyphosate and its degradate aminomethylphosphonic acid in the atmosphere. Environmental Toxicology and Chemistry 30, 548-555.

Coote, D.R., Dumanski, J., Ramsey, J.F. 1981. Assessment of degradation of agricultural lands in Canada. Research Branch, Agriculture Canada. Ottawa, Ontario.

Coupe, R.H., Manning, M.A., Foreman, W.T., Goolsby, D.A., Majewski, M.S. 2000.

Occurrence of pesticides in rain and air in urban and agricultural areas of Mississippi, AprilSeptember 1995. The Science of the Total Environment 248, 227-240.

Duke, S.O., Bowles, S.B. 2008. Mini-review Glyphosate: a once-in-a-century herbicide. Pest. Manag. Sci. 64, 319-325.

Environment Canada. 2012. Canadian Climate Normals or Averages 1971-2000, National Climate Data and Information Archive [online]Retrieved: http://www.climate.weatheroffice.gc.ca/climate_normals/index_e.html [September 9, 2012].

Goolsby, D. A., Thurman, E. M., Pomes, M.L., Meyer, M.T., Battaglin, W.A. 1997. Herbicides and their metabolites in rainfall: origin, transport, and deposition Patterns across the States, 1990-1991. Environ. Sci. Technol. 31, 1325-1333.

Grover, R., Shewchuk, S.R., Cessna, A.J., Smith, A.E., Hunter, J.H. 1985. Fate of 2,4-D Isooctyl Ester after Application to a Wheat Field. Journal of Environmental Quality. 14:203-210. 
Grynkiewicz M., Polkowska Ż., Gorecki T., Namieśnik J. 2003. Pesticides in precipitation from an urban region in Poland (Gdańsk-Sopot-Gdynia Tricity) between 1998 and 2000. Water, Air, \& Soil Pollution 149, 3-16.

Hill, B.D., Harker, K.N., Hasselback, P., Moyer, J.R., Inaba, D.J., Byers, S.D. 2001. Phenoxy herbicides in Alberta rainfall: Potential effects on sensitive crops. Can. J. Plant Sci. 82, 481-484.

Hill B. D., Inaba D. J., Byers S. D., Grant C. A. 2003. Levels of "phenoxy" herbicides in prairie rainfall during 2000-2001. Can. J. Plant Sci. 83, 467-470.

Hoffman, R.S., Capel, P.D., Larson, S.J. 2000. Comparison of pesticides in eight U.S. urban streams. Environmental Toxicology and Chemistry 19, 2249-2258.

Humphries, D., Byrtus, G., Anderson, A. 2005. Glyphosate residues in Alberta's atmospheric deposition, soils and surface waters. Water Research Users Group. Alberta Environment. Pub No. T/806.

Lamprea K., Ruban V. 2011. Characterization of atmospheric deposition and runoff water in a small suburban catchment. Environmental Technology 32, 1141-1149.

Larney, F.J., Cessna, A.J., Bullock, M.S. 1999. Herbicide transport on wind-eroded sediment. J. Environ. Qual. 28, 1412-1421.

Lobb, D.A., Li, S., McConkey, B.G. 2010. Soil Erosion Risk. Pages 46-53. in Eilers, W., MacKay, R., Graham, L.and Lefebvre, A. (eds). Environmental Sustainability of Canadian Agriculture: Agri-Environmental Indicator Report Series - Report \#3. Agriculture and AgriFood Canada, Ottawa, Ontario.

Manitoba Agricultural Services Corporation. 2013. MMPP Variety Yield Data Browser. [online] Retrieved: http://www.mmpp.com/mmpp.nsf/mmpp_browser_variety.html [March 15, 2013].

Majewski, M.S., Capel, P.D. 1995 Pesticides in the atmosphere: distribution, trends, and governing factors. Ann Arbor Press Inc., Chelsea, Michigan, 214 pp.

Messing P.G., Farenhorst A., Waite D.T., McQueen D.A.R., Sproull J.F., Humphries D.A., Thompson, L.L. 2011. Predicting wetland contamination from atmospheric deposition measurements of pesticides in the Canadian Prairie Pothole region. Atmospheric Environment 45, 7227-7234.

Messing, P., Farenhorst A., Waite D., Sproull, J. 2013. Influence of usage and chemical-physical properties on the atmospheric transport and deposition of pesticides to agricultural regions of Manitoba, Canada. Chemosphere 90, 1997-2003. 
Messing, P., Farenhorst, A., Waite D.T., Sproull, J.F. 2014. Current-use herbicides in air as influenced by their estimated agricultural use at various distances from six sampling locations. Water, Air, \& Soil Pollution 225, 2013

Meijers ,R.T., Oderwald-Mullera, E., Nuhnb, P.A.N.M., Kruithofa, J. C. 1995. Degradation of pesticides by ozonation and advanced oxidation pages ozone: science \& engineering: The Journal of the International Ozone Association 17, 673-686.

Quaghebeur D., De Smet B., De Wulf E., Steurbaut W. 2004. Pesticides in rainwater in Flanders, Belgium: results from the monitoring program 1997-2001. J. Environ. Monit. 6, 182-190.

Raina R., Hall P., Sun L. 2010. Occurrence and relationship of organophosphorus insecticides and their degradation products in the atmosphere in western Canada agricultural regions. Environmental Science \& Technology 44, 8541-8546.

Rawn D.F.K., Halldorson T.H.J., Lawson B.D., Muir, D.C.G. 1999. A multi-year study of four herbicides in air and precipitation from a small prairie watershed. Journal of Environmental Quality 28, 898-906.

Scribner, A.E., Thurman, E.M., Goolsby, D.A., Meyer, M.T., Battaglin, W.A., Kolpin, D.W. 2005. Summary of Significant Results from Studies of Triazine Herbicides and Their Degradation Products in Surface Water, Ground Water, and Precipitation in the Midwestern United States During the 1990s. Scientific Investigations Report 2005-5094. U.S. Department of the Interior U.S. Geological Survey.

Singh, S.B., Das, T.K., Kulshrestha G. 2013. Persistence of herbicide fenoxaprop ethyl and its acid metabolite in soil and wheat crop under Indian tropical conditions. J. Environ. Sci. Health B. $48,324-30$.

Skipper, H.D., Volk, V.V. 1972. Biological and Chemical Degradation of Atrazine in Three Oregon Soils. Weed Science 20, 344-347.

Smith, A.E. 1985. Persistence and transformation of the herbicides [14C]Fenoxaprop-ethyl and [14C]Fenthiaprop-ethyl in two prairie soils under laboratory and Field Conditions. J. Agric Food Chem. 33, 483-488.

Smith, A.E. 1988. Persistence and transformation of the herbicide [14c]glufosinate-ammonium in prairie soils under laboratory conditions. J. Agric. Food Chem. 36, 393-397.

Smith, A.E., Belyk, M.B. 1989. Field persistence studies with the herbicide glufosinateammonium in Saskatchewan soils. Journal of Environmental Quality 18, 475-479.

Thurman, E.M., Cromwell, A.E.. 2000. Atmospheric transport, deposition, and fate of triazine herbicides and their metabolites in pristine areas at Isle Royale National Park. Environ. Sci. Technol. 34, 3079-3085. 
Todd, A., Struger, J. 2014. Changes in acid herbicide concentrations in urban streams after a cosmetic pesticides ban. Challenges 5,138-151.

University of Hertfordshire. 2013. The Pesticide Properties DataBase (PPDB) developed by the Agriculture \& Environment Research Unit (AERU), University of Hertfordshire, 2006-2013.

Van Dijk, H.F.G., Guicherit, R. 1999. Atmospheric dispersion of current-use pesticides: a review of the evidence from monitoring studies. Water, Air, \& Soil Pollution 115, 21-70.

Waite D., Cessna A., Grover R., Kerr L., Snihura A. 2004. Environmental concentrations of agricultural herbicides in Saskatchewan, Canada: Bromoxynil, dicamba, diclofop, MCPA, and trifluralin. Journal of Environmental Quality 33, 1616-1628.

Waite D., Bailey P., Sproull J., Quiring D., Chau D., Bailey J., Cessna A. 2005. Atmospheric concentrations and dry and wet deposits of some herbicides currently used on the Canadian Prairies. Chemosphere 58, 693-703.

Welch, M.A. 2012. Manitoba Pesticide Use 2011. Winnipeg Free Press [online]Retrieved: https://docs.google.com/spreadsheet/ccc?key=0AnZNmLdt1i3dGZmUVQ3RzQxUGNjbWY1VGVycVI1cnc\#gid=0 [October 20, 2012].

Wilson, J.L. 2012. Agricultural Pesticide Use Trends in Manitoba and 2,4-D Fate in Soil. Ph.D. Thesis. University of Manitoba: Canada.

Xiaoxu, C., Shuang, Y., Liju, H., Shujun, S., Yanan, Z., Wenming, L. 2011. Residues and dissipation of the herbicide fenoxaprop-p-ethyl and its metabolite in wheat and soil. Bulletin of Environmental Contamination \& Toxicology 87, 50-53. 